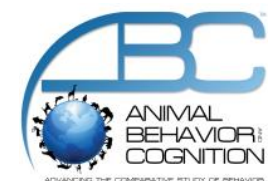

\title{
Cetacean Mother-calf Behavior Observed from a Small Aircraft off Southern California
}

\author{
Mari A. Smultea ${ }^{1,2 *}$, Dagmar Fertl ${ }^{3}$, Cathy E. Bacon ${ }^{4}$, Meggie R. Moore ${ }^{1}$, Vanessa R. James ${ }^{1}$, \\ \& Bernd Würsig ${ }^{2}$
}

\author{
${ }^{1}$ Smultea Environmental Sciences, Preston, WA \\ ${ }^{2}$ Marine Mammal Behavioral Ecology Group, Texas A\&M University at Galveston, Galveston, TX \\ ${ }^{3}$ Ziphius EcoServices, Magnolia, TX \\ ${ }^{4} \mathrm{HDR}$, Inc., San Diego, CA \\ *Corresponding author (Email: mari@ smulteasciences.com)
}

Citation - Smultea, M. A., Fertl, D., Bacon, C. E., Moore, M. R., James, V. R., \& Würsig, B. (2017). Cetacean mother-calf behavior observed from a small aircraft off Southern California. Animal Behavior and Cognition, 4(1), 1-23. https://doi.org/10.12966/abc.01.02.2017

\begin{abstract}
During early developmental stages, cetacean calves are dependent on their mothers for survival. Protection of young whales engaged in behaviors that are biologically important is critical for population recovery, so that appropriate management actions can be taken to minimize human disturbance. However, the occurrence and frequency of whale nursing and calves back-riding their mothers (both considered important to calf survival) have rarely been observed nor adequately quantified or defined. Therefore, it may not always be clear when disruption is occurring. We used extended behavioral observations, still photography, and video camera footage obtained during aircraft surveys in the Southern California Bight in 2008 - 2013 to characterize cetacean mother-calf interactions. Based on observations of four mother/calf pairs (two gray whale, Eschrichtius robustus, one fin whale, Balaenoptera physalus, and one blue whale, B. musculus) and one killer whale presumed mother/yearling pair (Orcinus orca), we describe bouts of nursing and calves riding on the backs of their presumed mothers, including activity duration, frequency, and relative body positioning. We conclude with specific definitions useful to wildlife conservation agencies authorizing and establishing restrictions to certain human activities when they might constitute behavioral disruptions.
\end{abstract}

Keywords - Gray whale, Eschrichtius robustus, Blue whale, Balaenoptera musculus, Fin whale, Balaenoptera physalus, Killer whale, Orcinus orca, Nursing, Back-riding, Calf

Protection of large whale species, particularly calves, from potential human disturbance is critically important for population recovery. During early developmental stages, cetacean calves like other mammalian young, are dependent on their mothers for survival including for food intake via nursing, protection from predators, and energy conservation (Whitehead \& Mann, 2000). Baleen whale calves have a short and intense lactation period (e.g., 6-7 months for blue and fin whales, Balaenoptera musculus and B. physalus, respectively; Lockyer, 1981) resulting in a high daily caloric cost of lactation due to the compressed time to calf independence (Hayssen, 1993; Oftedal, 1997). For example, Oftedal (1997) reported that mean fat content of milk consumed by blue, fin, and gray whale (Eschrichtius robustus) calves ranged from 41 to $53 \%$, with a corresponding estimated calf growth rate of $1.71 \mathrm{~cm}$ per day for the 
gray whale (Best, 1982; Cartwright et al., 2016). Furthermore, many baleen whales seasonally migrate long distances between high-latitude summer feeding grounds and lower-latitude winter calving grounds where the mother fasts in tropical waters characterized by low biological productivity (Ford \& Reeves, 2008). Although the impacts of disruptive anthropogenic activities on the reproductive success of individual whales are unknown (Clapham, 1999), interruption of nursing may reduce caloric intake of cetacean calves, which could be detrimental to calf survival. However, characteristics of wild cetacean mother-calf behaviors considered critical to survival (e.g., nursing), especially among baleen whales, are rarely documented. This is due to difficulties inherent in observing these animals that spend most of their life underwater, and often in hard-to-access oceanic areas. Further, it is difficult to obtain observations unbiased by the observer (e.g., a human diver) or observation platform (e.g., noise-producing vessels). An understanding of behavior that is biologically important to whale offspring survival is essential to conservation and recovery so that appropriate management action can be taken to minimize human disturbance. However, the occurrence, duration and frequency of whale nursing and calves back-riding their mothers, both considered important to calf survival, have rarely been observed and have not been adequately quantified or defined; therefore, it may not always be clear when disruption is occurring.

Apparent nursing by baleen whales has been observed from vessels, airplanes, and elevated shore stations, by human swimmers, and more recently using video footage obtained from small, overflying drones. The most detailed descriptions are for North Atlantic right (Eubalaena glacialis), South Atlantic right (Eubalaena australis), and bowhead (Balaena mysticetus) whales (Hain, Hampp, McKenney, Albert, \& Kenney, 2013; Thomas \& Taber, 1984; Würsig, Dorsey, Fraker, Payne, \& Richardson, 1985). Brief and/or anecdotal descriptions of apparent nursing exist for humpback (Megaptera novaeangliae), gray, and Bryde's (Balaenoptera edeni) whales (e.g., Glockner-Ferrari \& Ferrari, 1985; Reeves, Smith, Lund, Lebo, \& Josephson, 2010; Steiner, Silva, Zereba, \& Leal, 2007; Swartz, 1986; Sychenko, 2011; Williamson, 1961). Video recently obtained from drones documented blue whale mother-calf pairs in apparent nursing positions off southern California (Dana Point Whalewatching, 2016; Giradeau, 2015), Sri Lanka (Dykstra, 2013), and New Zealand (pygmy blue whale, Balaenoptera musculus brevicauda, Torres \& Klinck, 2016).

Apparent nursing among mysticetes has been reported during rest or slow travel with the mother and calf partially exposed at the water surface, only the calf below the surface, or both animals below the surface. South Atlantic right whale and bowhead whale nursing "bouts" were typically separated by the calf breathing one to three times at the surface, subsequently submerging for more nursing, and ending with a deeper dive (Thomas \& Taber, 1984; Würsig et al., 1985). Assumed nursing (i.e., "suckling") by North Atlantic right whales occurred when the calf's head maintained alignment with the mother's teats, followed by the calf surfacing and then nursing on the opposite side of the mother, alternately repeating this behavior (Hamilton \& Cooper, 2010). In contrast to balaenids, apparent nursing by Eschrichtiidae and Balaenopteridae calves is anecdotally reported to occur below the surface during both rest and slow travel. Sychenko (2011) defined apparent nursing among western gray whales as the mother rolling and the calf diving under her to nurse. Apparent nursing by humpback whales occurred with the mother and calf in a horizontal position (Glockner, 1983); a vertical position (head up; Bauer, 1986); or occasionally at the surface with the mother's flukes extending into the air (e.g., Bauer, 1986; Morete, Freitas, Engel, Pace, \& Clapham, 2003). Drone video showed different blue whale calves in an apparent nursing position with the mother resting at or near the surface and the calf below the surface with its rostrum oriented to the mother's teat area, usually with the calf dorsal side up but also ventral side up or on its side (Dana Point Whalewatching, 2016; Dykstra, 2013; Giradeau, 2015; National Geographic, 2016).

\section{Study Objectives}

The objective of our study was to conduct focal group and individual behavioral observations of cetaceans using video from an aircraft, focusing on pairs of mother-calf whales as a critical component of population conservation. We use results to provide definitions of vital mother-calf behavior useful to 
develop conservation and management measures aimed at minimizing disturbance to these biologically significant behaviors. Focal species included the endangered blue and fin whales, and the gray and killer (Orcinus orca) whales.

\section{Method}

\section{Aerial Survey Protocol}

Aerial surveys for marine mammals were flown in the Southern California Bight two to four times per year ( 7 - 10 days per survey) from 2008 through 2013 (see Smultea, 2016 for detailed methodology). The survey area extended from the coastline to approximately $200 \mathrm{~km}$ offshore from San Diego north to near Los Angeles, California (centered around 32 54' 19.6” N $118^{\circ} 22^{\prime} 49.8$ W). Surveys were conducted at an altitude of $244-305 \mathrm{~m}$ and 100 knots ground speed, primarily from a high-wing, twin-engine Partenavia P68 and glass-nosed Observer ( $n=17$ surveys), with the remaining survey made from an Aero Commander aircraft. Observation effort occurred throughout each flight focused along systematic transect lines following conventional distance sampling protocol (Buckland, Rexstad, Marques, \& Oedekoven, 2015). Two observers searched for marine mammals on each side of the aircraft through a bubble window while a recorder collected data on a laptop running customized data collection and mapping software, including Mysticetus ${ }^{\mathrm{TM}}$ (www.mysticetus.com). Sighting position information was calculated and plotted on a laptop map screen in real time by Mysticetus based on the horizontal bearing and declination angle to the sighting measured with a clinometer. Observer voices were recorded throughout each flight by taping a mini-microphone into a headphone earpiece connected to a portable voice recorder.

When a mother-calf whale pair was sighted, the plane circled the sighting at radial distance $0.5-$ $1 \mathrm{~km}$ and a target altitude of $457 \mathrm{~m}$ to collect extended detailed behavioral observations (i.e., focal follow); flying a small aircraft in this manner has been shown to avoid potential disturbance of whales by flying outside Snell's air-to-water sound transmission cone (Richardson, Greene, Malme, \& Thomson, 1995; Urick, 1972). All-occurrence focal individual and focal group sampling methods were used to record behavioral states (travel, mill, rest, unknown) and events following an ethogram (Altmann, 1974; Mann, 1999; Smultea, 2016). In addition, minimum and maximum distance between nearest neighbors as a measure of cohesion within a group (estimated in number of adult species body lengths [BL]) and magnetic orientation were recorded once per minute. A calf was defined as an animal less than threequarters the body length of the closely accompanying adult (i.e., within one-half adult BL). A yearling was defined as an animal estimated to be approximately three-quarters the BL of the closely accompanying adult whale (Taber \& Thomas, 1982). Photographs and video were taken to document species and behaviors through an open porthole window using a Canon EOS 40D or 60D or a Nikon D300 or D7000 DSLR camera with a 100 - $400 \mathrm{~mm}$ f/4.5-5.6 IS USM lens and a high-definition Sony Handycam HDR-XR550 or HDR-XR520 video camera.

Photographs and video were examined post-survey on a computer monitor to transcribe the frequency, duration, body orientation, distance between mother and calf, and laterality (i.e., mother's left or right side) of apparent nursing, back-riding events, and/or behavioral states. Distance between mother and calf were noted at $30 \mathrm{~s}$ intervals using instantaneous sampling methodology following the protocol of Taber and Thomas (1982). We defined back-riding as the calf touching or within one-quarter adult BL of the mother, positioned between the tail stock and the mother's head/rostrum. We defined apparent nursing as the mother and calf separated by less than one-quarter adult BL with the calf's head oriented towards the mother's teat area or peduncle for at least $5 \mathrm{~s}$. We did not observe the presence of milk and thus could not confirm that milk was transferred to the calf during apparent nursing. Duration of apparent nursing (i.e., a "session") was defined as the elapsed time from when the calf began then moved out of an apparent nursing position (based on video transcription, field notes, and/or voice recordings). Periods (in elapsed time as displayed on the monitor screen) when the calf and/or mother dove out of sight of the 
observer and/or video camera were also recorded. Whales were typically visible below the water surface to a depth of about $1-3$ adult BL, depending on conditions (e.g., water clarity, cloud cover, Beaufort Sea State). Travel speed in kilometers per hour $(\mathrm{km} / \mathrm{hr})$ of mother-calf pairs was calculated based on the distance between the first and last GPS positions of each sighting divided by the focal follow duration (in hours).

\section{Results}

In 2008 - 2013, we conducted 87,735 km of observation effort during 18 aerial surveys totaling 97 flights in the Southern California Bight; at least one survey occurred during every month except December (see Smultea, 2016). Focal follows were conducted on 160 cetacean groups for periods of 5 $60 \mathrm{~min}$ totaling $37.5 \mathrm{hr}, 4.3 \mathrm{hr}(11 \%)$ of which consisted of nine different mysticete whale mother-calf pairs. We observed apparent nursing and back-riding among four mysticete (two gray, one blue, and one fin whale) mother-calf pairs during observation periods of $19-54 \mathrm{~min}$, all of which were documented with video except one gray whale mother-calf pair documented by field notes and voice recording only (Table 1). We also photographed apparent nursing by one adult/yearling killer whale pair. From our overhead aerial perspective, all observed apparent nursing occurred with the mother motionless or traveling slowly at the surface and the calf below the surface. Back-riding and apparent nursing by the calf was nearly evenly distributed laterally on both sides of the mother across whale species (Table 2).

\section{Gray Whale: Nursing and Back-riding}

On 15 February 2011, we conducted a focal follow on a lone gray whale mother-calf pair for 30 min as they traveled slowly southeast at a mean speed of $3.6 \mathrm{~km} / \mathrm{hr}$ approximately $16 \mathrm{~km}$ from shore over a bottom depth of $580 \mathrm{~m}$. The calf was estimated to be one-half the mother's BL based on video analysis. The pair was at or near the water surface and within view of the observers for $83 \%$ of the 30 -min video recording. The pair was always observed within one-quarter mother BL of each other. One $15 \mathrm{~s}$ apparent nursing session was video-recorded (Table 1). The calf rode the mother's back 11 times with approximately equal frequency on the mother's left and right sides, of which 7 periods could be timed from start to finish ( $M=12 \mathrm{~s}, \mathrm{SD}=9.8, n=7$; Table 1, Figure 1). Back-riding typically involved the following chronological behavioral sequence by the calf: (1) "lying" on one side of the mother's peduncle for several minutes as she swam slowly just below the water surface; (2) quickly ( $3-20 \mathrm{~s}$ duration) crossing over the mother's back; and (3) lying again on the other side of the mother's peduncle for several more minutes. Each time, the calf's travel appeared to be due to the mother's propulsion, with no calf fluke movement evident; however, the mother's flukes beat intermittently throughout the focal follow. The last observed behavior was the calf back-riding in a different manner, with its lower peduncle positioned near the mother's flukes, floating back and forth near the center of the mother's back as though propelled by the mother's fluke beats.

On 19 April 2011, a lone gray whale mother-calf pair slowly traveled northbound at a mean speed of $4.3 \mathrm{~km} / \mathrm{hr}$ approximately $3 \mathrm{~km}$ from shore over a bottom depth of $30 \mathrm{~m}$ (Table 1). No video or photo was obtained for this focal follow. The calf was approximately one-half the mother's BL. The pair was at or near the water surface and within view of the observers for $85 \%$ of the $19.2 \mathrm{~min}$ focal follow. The whales were always observed within one-quarter to one mother BL of each another. Three apparent nursing sessions, each lasting $20-76 \mathrm{~s}$, were seen, always while the mother was motionless at the water surface with both pectoral fins outstretched and the calf below the surface (Table 1). The calf back-rode the mother three times for periods of $60-90 \mathrm{~s}$, rotating between the left (once) and right (twice) sides of the mother's peduncle area. 


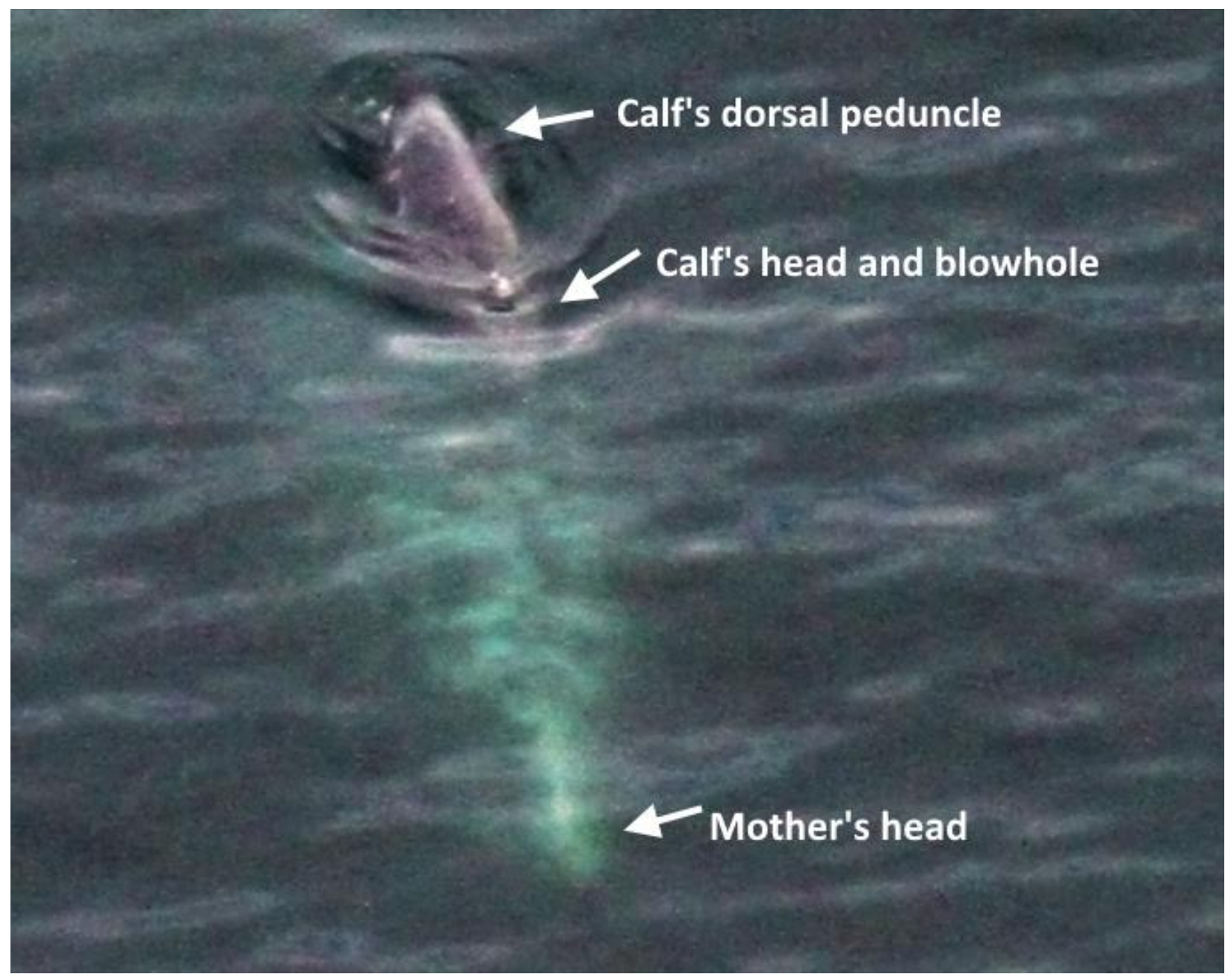

Figure 1. Gray whale calf at the water surface back-riding the rear left peduncle area of its mother as she swims below the water surface (mother has lighter body color) on 15 February 2011. Apparent nursing also was observed as the mother rested at the surface. Photograph by Bernd Würsig, NMFS permit 14451.

\section{Blue Whale: Nursing and Back-Riding}

On 24 May 2013, we conducted a 54 min focal follow on a lone blue whale mother-calf pair traveling slowly (approximately $3-4 \mathrm{~km} / \mathrm{hr}$ ) sub-surface $12 \mathrm{~km}$ from shore over a bottom depth of 290 $\mathrm{m}$. The calf was estimated to be one-half the mother's BL. The whales were within view of observers for $71 \%$ of the $54 \mathrm{~min}$ focal follow, $39 \mathrm{~min}$ of which was captured on video; photographs were taken after the video ended. The pair was always observed within one-quarter to one mother BL of each another, except near the end of the focal follow when the calf moved 2 BL away as a small $(<10 \mathrm{~m})$ outboard recreational boat approached to within $100 \mathrm{~m}$, stopped for several minutes, then abruptly departed. We observed four apparent nursing sessions of $13-264$ s duration each, three of which were recorded on video before the close approach by the small vessel (Table 1). The longest apparent nursing session of $264 \mathrm{~s}$ occurred after the small boat departed. Back-riding occurred four times with equal frequency on each side of the mother for periods of $8-94 \mathrm{~s}$ (Table 1). 
Table 1

Summary of Whale Nursing and Back-Riding Behaviors Observed Among Mother-Calf Pairs in the Southern California Bight

\begin{tabular}{|c|c|c|c|c|c|c|c|c|c|}
\hline \multirow[b]{2}{*}{ Species $^{\mathrm{a}}$} & \multirow[b]{2}{*}{$\begin{array}{c}\text { Obs. } \\
\text { Method }\end{array}$} & \multirow[b]{2}{*}{ Date } & \multirow[b]{2}{*}{$\begin{array}{l}\text { Total Obs. } \\
\text { Time (min) }\end{array}$} & \multirow[b]{2}{*}{$\begin{array}{l}\text { Max. Space in } \\
\text { Adult BL }\end{array}$} & \multicolumn{3}{|c|}{$\begin{array}{c}\text { Apparent Nursing } \\
\text { Session Duration (s) } \\
\end{array}$} & \multicolumn{2}{|c|}{ Back-riding } \\
\hline & & & & & Mean (SD) & Range & $n$ & $n$ & $\begin{array}{l}\text { Laterality } \\
(\mathbf{L} / \mathbf{R})\end{array}$ \\
\hline Gray whale & $\mathrm{V} \& \mathrm{P}$ & 15 Feb 2011 & 30 & 0.25 & $15(\mathrm{~N} / \mathrm{A})^{\mathrm{b}}$ & N/A & 1 & 11 & $6 / 5$ \\
\hline Gray whale & $\mathrm{N}$ & 19 Apr 2011 & 16 & 1 & $42(21)$ & $20-76$ & 3 & 3 & $1 / 2$ \\
\hline Blue whale & $V \& P$ & 24 May 2013 & 44 & 1 & 149 (132) & $13-264$ & 4 & 4 & $2 / 2$ \\
\hline Fin whale & $V \& P$ & 6 Jun 2009 & 50 & 1 & $90(45)$ & $30-138$ & 3 & 10 & $5 / 5$ \\
\hline Killer whale ${ }^{c}$ & $\mathrm{P}$ & 21 Nov 2009 & 40 & -- & -- & -- & -- & -- & -- \\
\hline
\end{tabular}

Note. $\mathrm{N}=$ documented with notes and voice recording only; $\mathrm{V} \& \mathrm{P}=$ documented with video and photographs; $\mathrm{BL}=$ adult body length(s).

aaximum estimated distance in adult BL observed between the presumed mother and calf.

bD not applicable due to sample size of 1 .

cAdult-yearling killer whale pair; all other sightings are mother-calf pair. Parameters for which no systematic data were collected are denoted with a dash. 
Table 2

Reports of Apparent Nursing (N) or Back-Riding (B) by Cetacean Calves in Free-Ranging and Captive Environments

Species

Mysticetes

North Atlantic right whale (Eubalaena glacialis)

South Atlantic right whale (Eubalaena australis)

Bowhead whale (Balaena mysticetus)

Blue whale (Balaenoptera musculus)

Pygmy blue whale (Balaenoptera musculus brevicauda)

Fin whale (Balaenoptera physalus)

Bryde's whale (Balaenoptera edeni/brydei)

Humpback whale (Megaptera novaeangliae)

Gray whale (Eschrichtius robustus)

Odontocetes

Sperm whale (Physeter macrocephalus)

Beluga whale (Delphinapterus leucas)

Killer whale (Orcinus orca)

Short-finned pilot whale (Globicephala macrorhynchus)

False killer whale (Pseudorca crassidens)

Rough-toothed dolphin (Steno bredanensis)

Dusky dolphin (Lagenorhynchus obscurus)

Bottlenose dolphin (Tursiops spp.)

Hybrid: bottlenose and rough-toothed dolphin

Atlantic spotted dolphin (Stenella frontalis)

Spinner dolphin (Stenella longirostris)

Short-beaked common dolphin (Delphinus delphis)

Humpback dolphin (Sousa plumbea)

Commerson's dolphin (Cephalorhynchus commersonii)

Finless porpoise (Neophocaena phocaenoides)

Harbor porpoise (Phocoena phocoena)
Calf Behavior

N, B

N, B

N, B

$\mathrm{N}$

$\mathrm{N}$

N

$\mathrm{N}$

$\mathrm{N}, \mathrm{B}$

N, B

N, B

N, B

$\mathrm{N}$

N

$\mathrm{N}$

$\mathrm{N}$

$\mathrm{N}$

$\mathrm{N}$

N

$\mathrm{N}$

N

$\mathrm{N}$

N

$\mathrm{N}$

N, B

$\mathrm{N}$

Note. See Appendix A for a list of supporting references. 


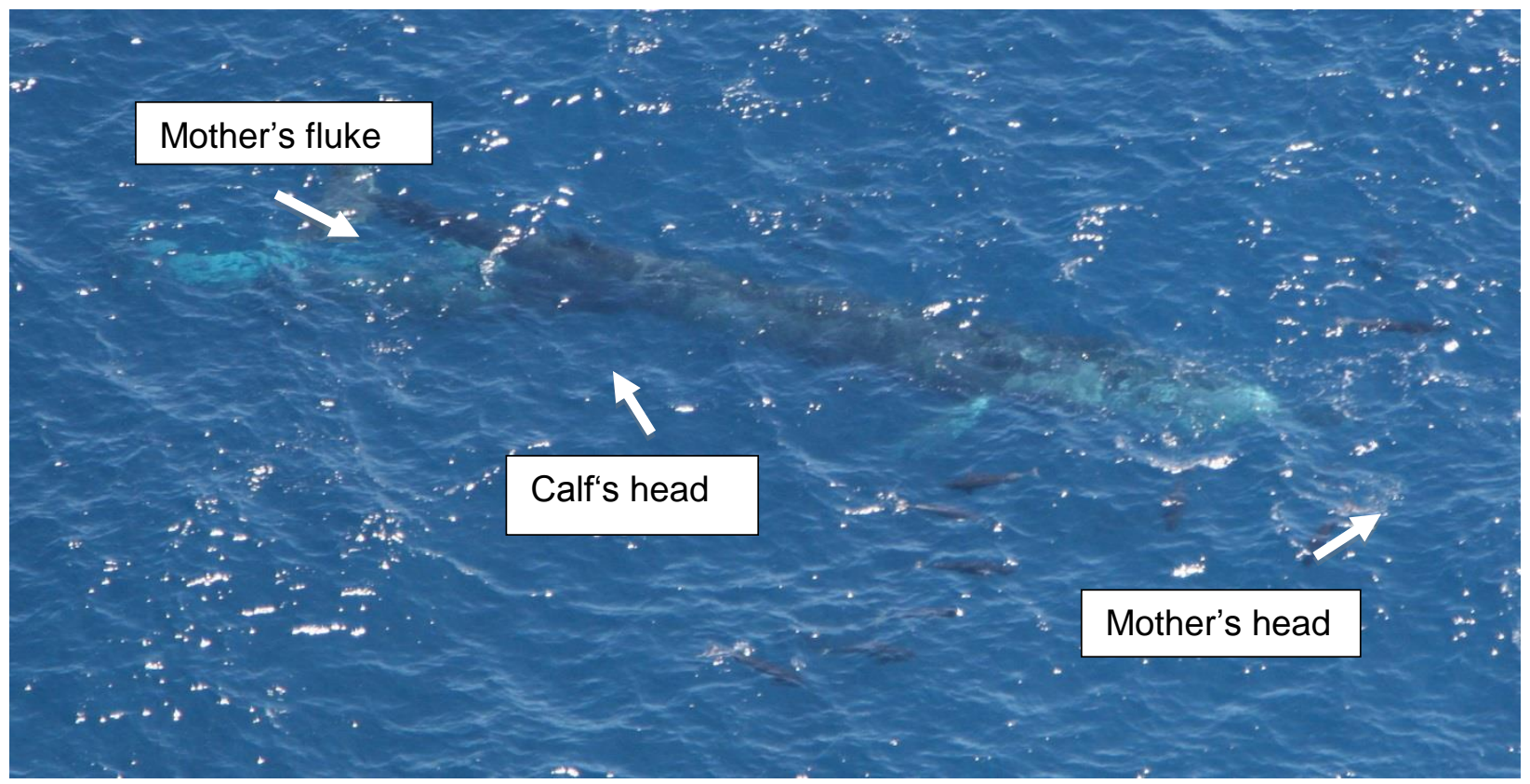

Figure 2. Apparent nursing by a fin whale calf (on upper left with white-colored ventral area visible below surface and head oriented toward the mother's teat area; mother's body is dark-colored to right) on 6 June 2009. Photograph by Lori Mazucca, NMFS permit 14451.

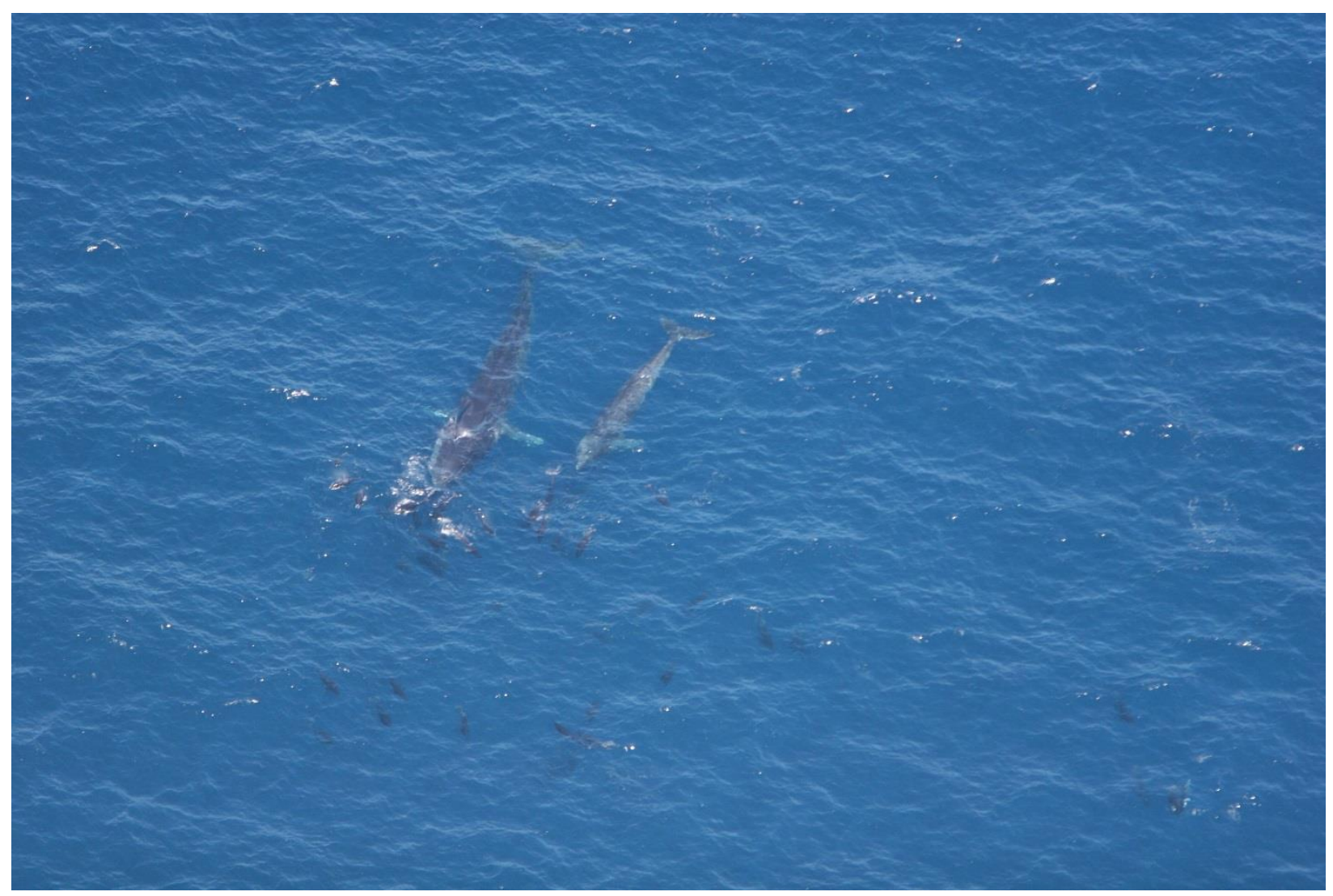

Figure 3. Same fin whale mother-calf pair as depicted in Figure 2, following and interacting with northern right whale dolphins on 6 June 2009. Photograph by Lori Mazucca, NMFS permit 14451. 


\section{Fin Whale: Nursing and Back-Riding}

On 6 June 2009, we conducted a 50 min focal follow on a fin whale mother-calf pair as they closely followed an estimated 1,000 northern right whale dolphins (Lissodelphis borealis) approximately $28 \mathrm{~km}$ from shore over a bottom depth of $785 \mathrm{~m}$. The fin whale pair traveled southwest at a mean speed of $6.6 \mathrm{~km} / \mathrm{hr}$, always at the rear of the dolphin group. The calf was approximately two-thirds the mother's $\mathrm{BL}$ and always remained within one mother BL next to or ahead of her. The mother-calf pair was visible at or near the water surface for $84 \%$ of the $50 \mathrm{~min}$ video-recorded focal follow. Apparent nursing was observed and photographed when the calf swam below the mother's peduncle/teat area in a generally perpendicular position relative to the mother including with the calf ventral-side up (Figure 2). Apparent nursing occurred for periods of $31-138 \mathrm{~s}$ (Table 1), while the calf remained below the surface as intermittently visible on the video. The calf occasionally appeared to play with individual dolphins by moving towards the dolphins and initiating physical contact with its head (Figure 3 ). The calf rode the mother's back on 10 occasions $(M=21 \mathrm{~s}, S D=13.8, n=10)$, equally split between the left and right sides of the mother (Table 1).

\section{Killer Whale: Nursing}

On 21 November 2009, we circled a group of 55 killer whales (including three calves and a yearling) in three subgroups as they traveled slowly southeast at a mean speed of $10.4 \mathrm{~km} / \mathrm{hr}$ approximately $28 \mathrm{~km}$ from shore over a bottom depth of about $785 \mathrm{~m}$. These individuals were likely from the offshore killer whale ecotype based on group size, location, and "closed" saddle patches (K. Balcomb, Center for Whale Research, personal communication, 19 January 2013). Approximately 250 photographs were taken, three images which captured apparent nursing among the same adult female and a smaller apparent yearling in two different nursing positions. The first position involved the adult and yearling lying on their sides, parallel to each other. Flukes were oriented in the same direction, and the whales' ventral sides faced each other while the yearling's rostrum was positioned at the adult's peduncle area. The whales were underwater, but the yearling's posterior end was at the surface (Figure 4A). In the second position, the adult swam on her back with the yearling lying on top of her. Again, their bodies exhibited the same orientation, and the yearling's rostrum was positioned at the adult's teat area while the adult was completely submerged. The yearling was also submerged, except for the dorsal fin (Figure 4B). Each of the two nursing positions lasted about $4-5 \mathrm{~min}$. Apparent nursing was based on the position of the yearling's mouth in proximity to the accompanying adult female's teats, the prolonged travel in this position, reports of similar nursing positions in captive killer whales (Asper, Young, \& Walsh, 1988; Clark \& Odell, 1999), the yearling's estimated age, and review of the photos by killer whale experts (K. Balcomb and D. Ellifrit, Center for Whale Research, personal communication, 19 and 22 January 2013, respectively). 
A)

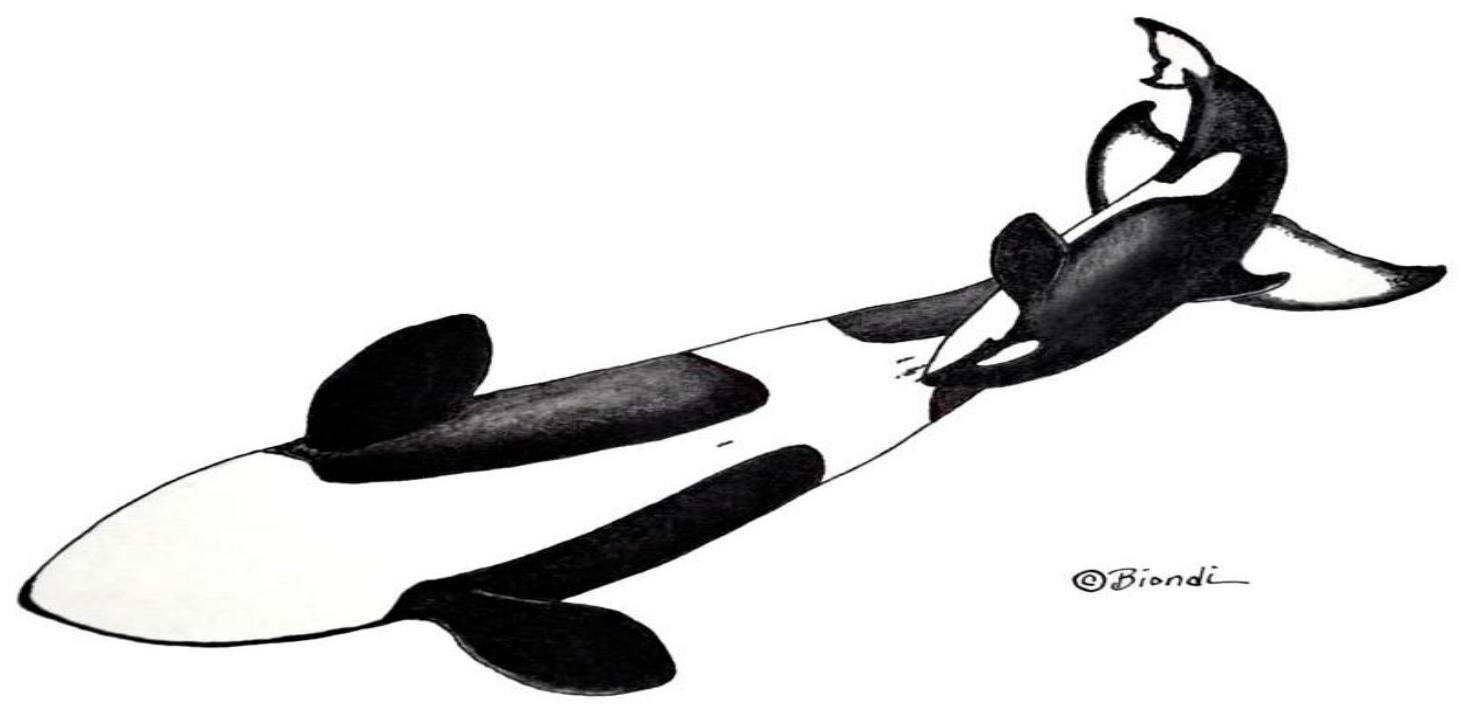

B)

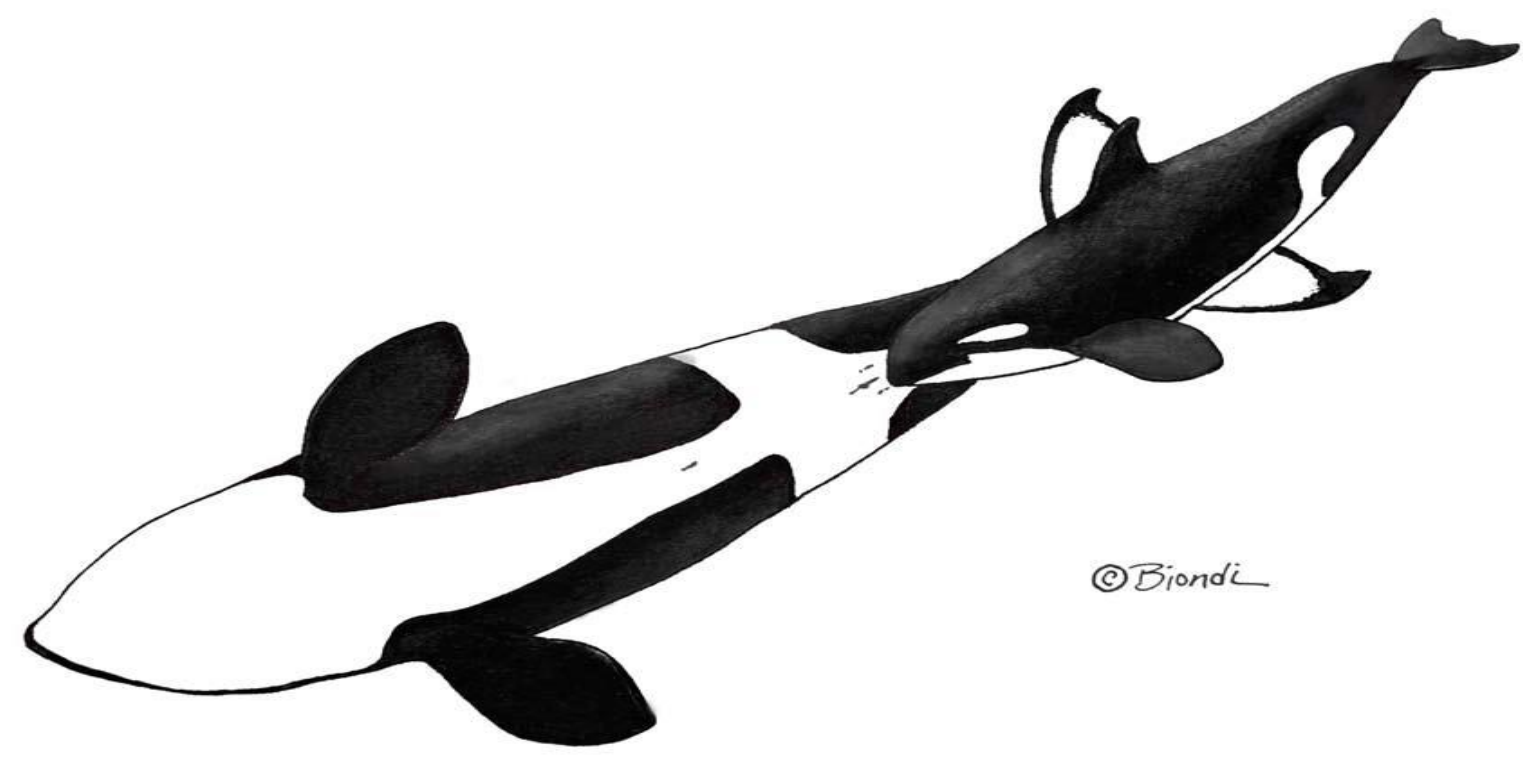

Figure 4. Two positions of a presumed mother killer whale nursing her yearling calf. A) Ventral-swimming calf nursing from ventral-swimming mother. B) Dorsal-swimming calf nursing from ventral swimming mother. Drawn from photographs taken off Southern California on 27 November 2009. 


\section{Discussion}

Our observations of apparent nursing and back-riding behavior were characterized by definable parameters that may also be useful indices of potential human disturbance/threat. This information facilitates recognition of critical behavior in the wild relative to implementation of management regulations specifically aimed at protecting cetacean mother-calf pairs. Comparisons of our observations with other studies suggest several patterns for apparent nursing and back-riding among mysticetes and killer whales that contribute to further understanding of mother-calf behaviors: (1) mother-calf positions were similar among mysticete species with a few exceptions, and were similar for captive and freeranging killer whales; (2) apparent nursing and back-riding always included the mother and calf remaining within one-half adult BL of one another; (3) back-riding occurred relatively frequently; (4) durations of apparent nursing were similar to the few mysticetes with available data; and (5) no preference for side of the mother (left or right) was evident among our small back-riding observation sample for mysticetes, in contrast to available data on killer whales and beluga whales.

\section{Apparent Nursing}

Our literature review revealed descriptions of nursing among at least 27 cetacean species or subspecies (Table 2). Duration of apparent nursing varies within and across mysticetes in the wild based on comparisons of our data with the few studies where data were systematically recorded. Among our gray, blue, and fin whale sightings, apparent nursing duration ranged from 13 to $264 \mathrm{~s}$ (Table 1). The longest gray whale apparent nursing duration was $76 \mathrm{~s}(M=45 \mathrm{~s}, S D=0.5, n=3)$. The blue whale mother-calf pair had the two longest apparent nursing durations of 260 and $264 \mathrm{~s}(M=149 \mathrm{~s}, S D=2.2, n=4)$, followed by the fin whale mother-calf pair at $138 \mathrm{~s}(M=90 \mathrm{~s}, S D=0.9, n=3)$. In comparison, six nursing submergences (measured as time from submergence to apparent nursing position to surfacing) for a bowhead whale calf previously separated from its mother for at least $71 \mathrm{~min}$ ranged from 10 to $27 \mathrm{~s}(M$ $=15.8, S D=6.37$; Würsig et al., 1985). Apparent nursing submergences of South Atlantic right whale calves less than one-year-old ranged from $<90 \mathrm{~s}$ as newborns to typically $90-120 \mathrm{~s}$ for yearlings (Thomas \& Taber, 1984). South Atlantic right whale infants also appeared to nurse at the mother's teat area for shorter periods $(M=2.7 \mathrm{~s}, S D=3.6, n=21)$ than yearlings $(M=6.8 \mathrm{~s}, S D=11.3, n=3)$ (Thomas \& Taber, 1984).

Our observations of a female killer whale swimming on her back with a yearling swimming above her and bumping her teat area during apparent nursing is similar to published accounts of observations of nursing among captive and free-ranging killer whales (Asper et al., 1988; Clark \& Odell, 1999; Condy, Van Aarde, \& Bester, 1978), and unpublished video-documented observations (i.e., drone flight video [Press, 2015]). Based on the size/age of the yearling in our observations, it is also possible that the mother rolled onto her back to terminate the nursing session, as similarly suggested occasionally for South Atlantic right whales (Payne, 1995; Payne \& Dorsey, 1983; Sironi, 2004; Thomas \& Taber, 1984). Comparable behavior was observed among both captive and free-ranging killer whales in which, nursing occurred when the calf swam on its side at about a 45-degree angle with its mouth placed on either teat (Asper et al., 1988; Clark \& Odell, 1999).

\section{Back-riding by Calves}

We observed a calf riding the presumed mother's back near the peduncle area among blue, fin, and gray whales. Back-riding behavior by calves previously was reported for an additional five cetacean species (Table 2 herein) (Hain, et al., 2013; Morete, Bisi, \& Rosso, 2007; Pilleri \& Chen, 1979; Thomas \& Taber, 1984; Würsig, Koski, \& Richardson, 1999). The diversity of cetacean species that display backriding by calves supports the hypothesis that its adaptive benefits include locomotion energy savings for the calf via "drafting," particularly for young, less-agile calves, and during migration (e.g., Caron, 1987; 
Noren, 2008; Swartz, 1986; Taber \& Thomas, 1982; Würsig et al., 1999). Back-riding also appears to serve adaptive significance during the critical first few months of a calf's life by facilitating physical contact and close proximity to the mother for protection while the calf is in its early, vulnerable developmental stages (Krasnova, Bel'kovich, \& Chernetsky, 2006). As documented among many mammals (e.g., Trivers, 1974), proximity of cetacean mothers and young calves and duration traveling near the mother decreases with increasing calf age, corresponding to larger size and increased calf dexterity (e.g., Cartwright, 2005; Krasnova et al., 2006; Mann \& Smuts, 1999; Thomas \& Taber, 1984). Although we found no laterality preference for back-riding among the four mysticete mother-calf pairs we observed, beluga and killer whale calves preferred the right side of their mothers while swimming, a bias attributed to right-hemispheric advantage resulting in left eye social preference, as described in other vertebrates and cetaceans (e.g., Karenina, Giljov, Ivkovich, Burdin, \& Malashichev, 2013; Krasnova et al., 2006).

Human-related activities involving underwater noise in the marine environment (e.g., seismic airguns, oil drilling, naval sonar, vessel traffic, pile driving, tourism) under some circumstances and received sound levels disturb and interrupt feeding, socializing, resting and diving patterns of cetaceans (e.g., Lundquist, Gemmell, \& Würsig, 2012; Melcón et al., 2012; Richardson et al., 1995; Southall et al., 2007), including mother and calf humpback whales (Lebrón, 2012; Morete et al., 2007). Anthropogenic disturbance of nursing by cetacean calves has not been demonstrated. However, Morete et al. (2007) noted the absence of back-riding and less rest and fewer active behavioral events (e.g., rolling) by humpback whale calves within $100 \mathrm{~m}$ of vessels. In response to close $(<10 \mathrm{~m})$ boat approaches, killer whale mothers shifted calf position from their right to their left side; the authors suggested that this response improved sensory information flow from the calf to the mother's left eye, resulting in right brain hemisphere advantage in visual acuity/responsiveness to a potential threat (Karenina et al., 2013). Calf laterality in mysticetes may also provide a quantitative measure of disturbance, though we did not find any lateral bias in our small sample size. Interruption of nursing and back-riding is of special concern given the endangered or threatened status of many large whale species, especially relative to the highenergy needs of fast-growing mysticete calves (e.g., Lebrón, 2012; Lockyer, 1981; Oftedal, 1997). Cumulative such disruptions could risk calf survival. To minimize and avoid such disturbance, a standardized definition of encompassing critical behavior is needed to ascertain and minimize such impacts.

Our small sample sizes reflect the difficulties inherent in observing whale mother-calf behavior in the wild. We describe herein how back-riding and apparent nursing occur when mother-calf whale pairs are in close proximity. Although we did not observe milk in the water, we believe that nursing likely occurs during this time. We thus recommend that mother-calf pairs not be disturbed when within one-half adult BL of each other. As such periods represent time that could be spent nursing or in other key behaviors including supported rest, protection of this behavior directly influences the potential survival of young in large cetaceans. Recent progress in the use of drones equipped with video cameras over clear waters (e.g., Durban, Fearnbach, Barrett-Lennard, Perryman, \& Leroi, 2015), and at distances unlikely to disturb whales and dolphins, should provide further details on important cetacean mother-calf behavioral interactions, though ascertaining the exchange of milk may still be problematic. Notwithstanding, we provide rare descriptions and summary statistics for apparent nursing and back-riding in the wild by calves for the endangered blue and fin whale, and the gray and killer whale. Apparent nursing and backriding as defined herein are biologically important behaviors that should not be interrupted by anthropogenic activities. Since accounts of nursing and back-riding behavior by free-ranging cetaceans are limited, our descriptions provide an important contribution of available information to identify and define mother-calf interactions biologically important to survival. 


\section{Acknowledgements}

We thank all who assisted with fieldwork, logistics, or data analysis: K. Ampela, J. Biondi (including whale sketches), C. Boerger, R. Braaten, J. Bredvik, M. Cotter, M. Deakos, D. Engelhaupt, A. Fowler, G.L. Fulling, S. Garrett, C. Goertz, J.C. Grady, C. Johnson, C. Kyburg, K. Lomac-MacNair, M. MacKay, L. Mazzuca, R. Merizan, J. Mobley, Jr., T. Norris, M. Richie, F. Robertson, D. Steckler, Aspen Helicopters (R. Throckmorton and pilots B. Hansen, C. Bartush, A. Blasingame, N. Carillo, M. Estomo, S. Jones, C. Kluzek, D. Moody, I. Ufford, and K. Veatch), and Smultea Environmental Sciences and the Marine Mammal Research Program. Funding was provided by U.S Navy, Commander, Pacific Fleet (CPF) under the U.S. Navy's Marine Species Monitoring Program, including through sub-agreements with Marine Mammal Research Consultants, Scripps Institution of Oceanography, Smultea Environmental Sciences, and HDR, Inc., under contract to Naval Facilities Engineering Command (NAVFAC). We thank C. Johnson at CPF, L. Mazzuca and S. Hanser at NAVFAC Pacific, J. Bredvik at NAVFAC Southwest, and K. Ampela at HDR for technical support, project management, and contractual support. This manuscript was improved by critical review from G. Silber, journal editor J. Vonk, and 3 anonymous reviewers. Data were collected under NMFS permit numbers 14451, 15369 and 774-1714-09, as part of $\mathrm{PhD}$ dissertation field work of author M.A. Smultea.

\section{References}

Altmann, J. (1974). Observational study of behavior: Sampling methods. Behaviour, 49, 227-267. doi:10.1163/156853974x00534

Asper, E. D., Young, W. D., \& Walsh, M. T. (1988). Observations on the birth and development of a captive-born killer whale. International Zoo Yearbook, 27, 295-304. doi:10.1111/j.1748-1090.988.tb03227.x

Bauer, G. B. (1986). The behavior of humpback whales in Hawaii and modifications of behavior induced by human interventions (unpublished doctoral dissertation). University of Hawaii, Honolulu, HI.

Best, P. B. (1982) Seasonal abundance, feeding, reproduction, age and growth in minke whales off Durban (with incidental observations from the Antarctic). Reports of the International Whaling Commission, 32, 759786.

Buckland S. T., Rexstad E. A., Marques T. A., \& Oedekoven, C. S. (2015). Distance sampling: Methods and applications. Cham, Switzerland: Springer International Publishing. doi:10.1007/978-3-319-19219-2

Caron, L. M. J. (1987). Status, site-fidelity, and behavior of a hunted herd of white whales (Delphinapterus leucas ${ }^{2}$ in the Nastapoka Estuary, eastern Hudson Bay. (Unpublished master's thesis), McGill University, Montreal, Quebec.

Cartwright, R. (2005). A comparative study of the behaviour and dynamics of humpback whale (Megaptera novaeangliae) mother and calf pairs during their residence in nursery waters. (Unpublished doctoral dissertation), Manchester Metropolitan University, Manchester, UK.

Cartwright, R., Newton, C., West, K. M., Rice, J., Niemeyer, M., Burek, K.,...Marcial-Hernandez, L. (2016). Tracking the development of muscular myoglobin stores in mysticete calves. PLoS ONE, 11, e0145893. doi:10.1371/journal.pone.0145893

Clapham, P. J., Young, S. B., \& Brownell, R. L. (1999). Baleen whales: Conservation issues and the status of the most endangered populations. Mammal Review, 29, 35-60. doi:10.1046/j.1365-2907.1999.00035.x

Clark, S. T., \& Odell, D. K. (1999). Nursing parameters in captive killer whales (Orcinus orca). Zoo Biology, 18, 373-384. doi:10.1002/(sici)1098-2361(1999)18:5<373:aid-zoo2>3.0.co;2-d

Condy, P. R., Van Aarde, R. J., \& Bester, M. N. (1978). The seasonal occurrence and behaviour of killer whales Orcinus orca, at Marion Island. Journal of Zoology, 184, 449-464. doi:10.1111/j.14697998.1978.tb03301.x

Dana Point Whalewatching. (2016, October 9). Blue whale nursing mother and calf [Video File]. Retrieved from https://www.youtube.com/watch?v=oTIDLcKpApQ

Durban, J. W., Fearnbach, H., Barrett-Lennard, L. G., Perryman, W. L., \& Leroi, D. J. (2015). Photogrammetry of killer whales using a small hexacopter launched at sea. Journal of Unmanned Vehicle Systems, 3, 131-135. doi:10.1139/juvs-2015-0020

Dykstra, P. (2013, June 17). Blue whale exploration - Sri Lanka [Video File]. Retrieved from : 
https://www.youtube.com/watch?v=KuXCTIdlXOk

Ford, J. K. B., \& Reeves, R. R. (2008). Fight or flight: Antipredator strategies of baleen whales. Mammal Review, 38, 50-86. doi:10.1111/j.1365-2907.2008.00118.x

Giradeau, M. G. [Mark G Media]. (2015, July 12). First known aerial of nursing blue whales [Video File] Retrieved from https://www.youtube.com/watch?v=9-_EJVI7Mns

Glockner, D. (1983). Determining the sex of humpback whales (Megaptera novaeangliae) in their natural environment. In R. Payne (Ed.), Communication and behavior of whales (pp. 447-464). Boulder, CO: Westview Press.

Glockner-Ferrari, D. A., \& Ferrari, M. J. (1985). Individual identification, behavior, reproduction and distribution of humpback whales, Megaptera novaeangliae, in Hawaii. Washington, DC: Marine Mammal Commission. (NTIS PB85-200772).

Hain, J. H. W., Hampp, J. D., McKenney, S. A., Albert, J. A., \& Kenney, R. D. (2013). Swim speed, behavior, and movement of North Atlantic right whales (Eubalaena glacialis) in coastal waters of northeastern Florida, USA. PLoS ONE, 8, e54340. doi:10.1371/journal.pone.0054340

Hamilton, P. K., \& Cooper, L. A. (2010). Changes in North Atlantic right whale (Eubalaena glacialis) cow-calf association times and use of the calving ground: 1993-2005. Marine Mammal Science, 26, 896-916. doi:10.1111/j.1748-7692

Hayssen, V. (1993). Empirical and theoretical constraints on the evolution of lactation. Journal of Dairy Science, 76, 3213-3233. doi: http://dx.doi.org/10.3168/jds.S0022-0302(93)77659-6

Karenina, K., Giljov, A., Ivkovich, T., Burdin, A. \& Malashichev, Y. (2013). Lateralization of spatial relationships between wild mother and infant orcas, Orcinus orca. Animal Behaviour, 86, 1225-1231. doi $10.1016 /$ j.anbehav.2013.09.025

Krasnova, V. V., Bel'kovich, V. M., \& Chernetsky, A. D. (2006). Mother-infant spatial relationships in wild beluga (Delphinapterus leucas) during postnatal development under natural conditions. Biological Bulletin, 33, 53-58. doi:10.1134/S1062359006010079

Lebrón, S. G. Q. (2012). Do calves matter? The effect of number of boats and mode of approach on the behavioral and acoustic responses of cetacean groups with calves (Unpublished master's thesis). University of Puerto Rico, Río Piedras, Puerto Rico.

Lockyer, C. (1981). Growth and energy budgets of large baleen whales from the Southern Hemisphere. In J. G. Clark (Ed.), FAO fisheries series 5: Mammals in the seas. Vol 3: General papers and large cetaceans (pp. 379-487). Rome: Food and Agriculture Organization of the United Nations.

Lundquist, D., Gemmell, N. J., \& Würsig, B. (2012). Behavioural responses of dusky dolphin groups (Lagenorhynchus obscurus) to tour vessels off Kaikoura, New Zealand. PLoS ONE, 7, e41969. doi:41910.41371/journal.pone.0041969.

Mann, J. (1999). Behavioral sampling methods for cetaceans: A review and critique. Marine Mammal Science, 15, 102-122. doi: 10.1111/j.1748-7692.1999.tb00784.x

Mann, J., \& Smuts, B. (1999). Behavioral development in wild bottlenose dolphin newborns (Tursiops sp.). Behaviour, 136, 529-566. doi:10.1163/156853999501469

Melcón, M. L., Cummins, A. J., Kerosky, S. M., Roche, L. K., Wiggins, S. M., \& Hildebrand, J. A. (2012). Blue whales respond to anthropogenic noise. PLoS ONE, 7, e32681. doi:32610.31371/journal.pone.0032681.

Morete, M. E., Freitas, A., Engel, M. H., Pace, R. M., \& Clapham, P. J. (2003). A novel behavior observed in humpback whales on wintering grounds at Abrolhos Bank (Brazil). Marine Mammal Science, 19, 694-707. doi:10.1111/j.1748-7692.2003.tb01125.x

Morete, M. E., Bisi, T. L., \& Rosso, S. (2007). Mother and calf humpback whale responses to vessels around the Abrolhos Archipelago, Bahia, Brazil. Journal of Cetacean Research and Management, 9, 241-248.

National Geographic. 2016, March 6. Exclusive video may show blue whale calf nursing. Retrieved from http://news.nationalgeographic.com/2016/03/160302-blue-whale-mother-calf-nursing-video-pygmy-newzealand/

Noren S. R. (2008). Infant carrying behaviour in dolphins: Costly parental care in an aquatic environment. Functional Ecology, 22, 284-288. doi:10.1111/j.1365-2435.2007.01354.x

Oftedal, O. T. (1997). Lactation in whales and dolphins: Evidence of divergence between baleen- and toothedspecies. Journal of Mammary Gland Biology and Neoplasia, 2, 205-230. doi:10.1023/A:1026328203526

Payne, R. (1995). Among whales. New York, NY: Scribner. 
Payne, R., \& Dorsey, E. M. (1983). Sexual dimorphism and aggressive use of callosities in right whales (Eubalaena australis). In R. S. Payne (Ed.), Communication and behavior of whales (pp. 295-332). Boulder, CO: Westview Press.

Pilleri, G., \& Chen, P. (1979). How the finless porpoise (Neophocaena asiaeorientalis) carries its calves on its back, and the function of the denticulated area of skin, as observed in the Changjiang River, China. Investigations on Cetacea, 10, 105-108.

Press, R. (2015). UAV reveals killer whales in striking detail. On the line: A NOAA fisheries podcast. Retrieved from: http://www.fisheries.noaa.gov/podcasts/2015/10/uav_killer_whale.html

Reeves, R. R., Smith, T. D., Lund, J. N., Lebo, S. A., \& Josephson, E. A. (2010). Nineteenth-century ship-based catches of gray whales, Eschrichtius robustus, in the eastern North Pacific. Marine Fisheries Review, 72, 26-65.

Richardson, W. J., Greene, C. R., Jr., Malme, C. I., \& Thomson, D. H. (1995). Marine mammals and noise. San Diego, CA: Academic Press.

Sironi, M. (2004). Behavior and social development of juvenile southern right whales (Eubalaena australis) and interspecific interactions at Peninsula Valdés, Argentina, (Unpublished master's thesis). University of Wisconsin, Madison, WI.

Smultea, M. A. (2016). Behavioral ecology of cetaceans in the Southern California Bight (Unpublished doctoral dissertation). Texas A\&M University at Galveston, Galveston, TX.

Southall, B. L., Bowles, A. E., Ellison, W. T., Finneran, J. J., Gentry, R. L., Greene, C. R., Jr., ...Tyack, P. L. (2007). Marine mammal noise exposure criteria: Initial scientific recommendations. Aquatic Mammals, 33, 411-521. doi:10.1578/AM.33.4.2007.415

Steiner, L., Silva, M. A., Zereba, J., \& Leal, M. J. (2007). Bryde's whales, Balaenoptera edeni, observed in the Azores: A new species record for the region. JMBA2-Biodiversity Records, 1. doi:10.1017/S1755267207007282

Swartz, S. L. (1986). Gray whale migratory, social and breeding behavior. Reports of the International Whaling Commission, Special Issue, 8, 207-229.

Sychenko, O. A. (2011). Western gray whale (Eschrichtius robustus) mother and calf ecology off Sakhalin Island. (Unpublished master's thesis). Texas A\&M University, College Station, TX.

Taber, S., \& Thomas, P. (1982). Calf development and mother-calf spatial relationships in southern right whales. Animal Behaviour, 30, 1072-1083. doi:10.1016/S0003-3472(82)80197-8

Thomas, P. O., \& Taber, S. M. (1984). Mother-infant interaction and behavioral development in southern right whales, Eubalena australis. Behaviour, 88, 42-60. doi:10.1163/156853984X00470

Torres, L., \& Klinck, H. (2016). Blue whale ecology in the South Taranaki Bight region of New Zealand. JanuaryFebruary 2016 Field Report. Oregon State University; Geospatial Ecology of Marine Megafauna Lab; and Cornell Lab, Bioacoustics Research Program.

Trivers, R. L. (1974). Parent-offspring conflict. American Zoologist, 14, 249-264. doi:10.1093/icb/14.1.249

Urick, R. J. (1972). Noise signature of an aircraft in level flight over a hydrophone in the sea. Journal of the Acoustical Society of America, 52(3, Part 2), 993-999. doi:10.1121/1.1913206

Whitehead, H., \& Mann, J. (2000). Female reproductive strategies of cetaceans. In J. Mann, R. C. Connor, P. L. Tyack, \& H. Whitehead (Eds.), Cetacean societies: Field studies of dolphins and whales (pp. 219-246). Chicago. IL: University of Chicago Press.

Williamson, G. R. (1961). Winter sightings of a humpback suckling its calf on the Grand Bank of Newfoundland. Norsk Hvalfangst-Tidende, 50, 1-5.

Würsig, B., Dorsey, E. M., Fraker, M. A., Payne, R. S. \& Richardson, W. J. (1985). Behavior of bowhead whales, Balaena mysticetus, summering in the Beaufort Sea: A description. Fishery Bulletin, 83, 357-377.

Würsig, B., Koski, W. R., \& Richardson, W. J. (1999). Whale riding behavior: Assisted transport for bowhead whale calves during spring migration in the Alaskan Beaufort Sea. Marine Mammal Science, 15, $204-210$. doi:10.1111/j.1748-76921999.tb00791.x 


\section{Appendix A}

Table A1

Reports of Apparent Nursing (N) or Back-Riding (B) By Cetacean Calves in Free-Ranging and Captive Environments

\section{Species}

North Atlantic Right Whale

(Eubalaena glacialis)

South Atlantic right whale Eubalaena australis

\section{Bowhead whale}

Balaena mysticetus

Blue whale

Balaenoptera musculus

Fin whale

Balaenoptera physalus

Bryde's whale

Balaenoptera edeni/brydei

Humpback whale

Megaptera novaeangliae

Gray whale

Eschrichtius robustus

Sperm whale

Physeter macrocephalus

Beluga whale

Delphinapterus leucas

Killer whale

Orcinus orca

Pilot whale

Globicephala sp.

Short-finned pilot whale

Globicephala macrorhynchus

False killer whale

Pseudorca crassidens

\section{Source}

Foley et al., 2011 (B); Hain et al., 2013 (N,B); Hamilton \& Cooper, 2010 (N)

Best et al., 2015 (N); Patenaude, 2000 (B); Santillian et al., 2004 (N); Thomas \& Taber, 1984 (B); Van Waerebeek et al., 1998 (N);

Boertmann \& Nielsen, 2010 (N); Carroll \& Smithhisler, 1980 (N,B); Richardson et al., 1990 (N,B); Würsig \& Clark, 1993 (N,B)

Würsig et al., 1983, 1984, 1985, 1986, 1999 (N,B)

Dana Point Whalewatching, 2016; Dykstra, 2013 (N); Giradeau, 2015 (N); National Geographic, 2016 (N); Torres \& Klinck, 2016 (N)

Edds \& MacFarlane, 1987 (N)

Notarbartolo di Sciara, 1983 (N); Steiner et al., 2007 (N)

Bauer, 1986 (N); Cartwright, 2005 (N,B); Cartwright \& Sullivan, 2009 (N); Deakos et al., 2010 (B); Clapham \& Mayo, 1987 (N); Edel \& Winn, 1978 (B); Ferreira et al., 2014 (B); Glockner \& Venus, 1983 (N); Glockner-Ferrari \& Ferrari, 1984, 1985 (N,B); Lefèvre et al., 1999 (N); Morete et al., 2003 (N); Scammon, 1874 (N); Uwagbae \& Van Waerebeek, 2010 (N) Van Waerebeek et al., 2001 (N)

Busch, 1998 (N); Reeves et al., 2010 (B); Swartz, 1986 (B); Sychenko, 2011 (N)

Bennett, $1840(\mathrm{~N})$; Berzin, 1972 (N); Best et al., 1984 (N); Bullen, 1889 (N); Dudley, 1725 (N,B); Gero \& Whitehead, 2007 (N); Gordon, 1987, 1991 (N); Johnson et al., 2010 (N); Whitehead, 2003 (N)

Béland et al., 1990 (B); Campbell, 2011 (N); Caron, 1987 (N,B); Chapskii, 1941 (as cited in Norris \& Dohl, 1980) (B); Drinnan \& Sadlier, 1981 (N); Hewlett, 1978 (N); Krasnova et al., 2006 (N,B); Leung et al., 2010 (N); Russell et al., 1997 (N); Sergeant \& Brodie, 1975 (B); Tomilin, 1967 (B)

Asper et al., 1988 (N); Clark \& Odell, 1999a (N); Condy et al., 1978 (N); Haenel, 1986 (N); Jacobsen, 1986 (N); Press, 2015 (N); Visser, $2000(\mathrm{~N})$

Starrett \& Starrett, 1955 (N)

Hofmann et al., $2004(\mathrm{~N})$

Clark \& Odell, 1999b (N) 
Table A1 (cont.)

Rough-toothed dolphin

Steno bredanensis

Dusky dolphin

Lagenorhynchus obscurus

Bottlenose dolphin (Tursiops truncatus and T. aduncus)

Hybrid: bottlenose and roughtoothed dolphin

Atlantic spotted dolphin

Stenella frontalis

Spinner dolphin

Stenella longirostris

Short-beaked common dolphin

Delphinus delphis

Pacific white-sided dolphin

Lagenorhynchus obliquidens

Humpback dolphin

Sousa plumbea

Commerson's dolphin

Cephalorhynchus commersonii

Finless porpoise

Neophocaena phocaenoides

Harbor porpoise

Phocoena phocoena

Note. Previously published records were reviewed and some did not meet criteria for inclusion. For example, a source that stated that suckling or nursing was observed without any detailed behavioral description (e.g., angle of the calf relative to the mother) was excluded. For example, Williamson (1961) states that suckling was observed, but no details were provided to confirm that interpretation, and this publication was considered suspect and is not presented in the table. Video documenting nursing (as defined herein) is included in this table.

Kuczaj \& Yeater, $2007(\mathrm{~N})$

Deutsch, 2008 (N); Markowitz, 2012 (N)

Amundin, 1999 (N); Barlowe et al., 2001 (N); Caldwell \& Caldwell, 1972 (N); Chirighin, 1987 (N); Clugston, 1974 (N); Cockcroft \& Ross, 1990 (N); Essapian, 1953 (N); Dohl et al., 1974 (N); Dudok van Heel \& Meyer, 1974 (N); Eastcott \& Dickinson, 1987 (N);

Fellner, $2000(\mathrm{~N})$; Gubbins et al., 1999 (N); Gurevich, 1977 (N); Jacobsen et al., 2003 (N); Kastelein et al., 1990 (N); Mann \& Smuts, 1999 (N); Mann et al., 2000 (N); McBride \& Kritzler, 1951 (N); Mello et al., 2005 (N); Morisaka et al., 2005 , 2010 (N); Peddemors et

al., 1992 (N); Rakhmawati, 2013 (N); Reid et al., 1995 (N); Ridgway et al., 1995 (N); Sakai et al., 2016 (N); Schroeder, 1990 (N); Stensland \& Berggren, 2007 (N); Tavolga \& Essapian, 1957 (N); von Streit et al., 2011, 2013 (N); Wells, 1991 (N)

Dohl et al., 1974 (N); Norris \& Dohl, 1980 (N)

Dudzinski, 1996 (N); Miles \& Herzing, 2003 (N)

Johnson \& Norris, 1994 (N); Norris \& Dohl, 1980 (N); Silva Jr. et al., 2005 (N)

Schaffar-Delaney, $2004(\mathrm{~N})$

ZooBorns, $2012(\mathrm{~N})$

Saayman \& Tayler, $1979(\mathrm{~N})$

Joseph et al., 1987 (N); Kastelein et al., 1993 (N); Sakai et al., 2013 (N)

Chen et al., 1979 (B); Kasuya, 1999 (B); Liu et al., 1986 (B); Pilleri \& Chen, 1979 (B); Wei et al., 2002 (B); Xian et al., 2010 (N, B):

Xian et al., $2012(\mathrm{~N})$

Camphuysen \& Krop, 2011 (N); Johnson et al., 2010 (N) 


\section{Appendix A References}

Amundin, M. (1999). Observations of reproduction in captive bottlenose dolphin, (Tursiops truncatus): Delivery, nursing, mother-calf interactions, social dynamics, and calf survival/mortality. European Research on Cetaceans, 12, 423-426.

Asper, E. D., Young, W. D., \& Walsh, M. T. (1988). Observations on the birth and development of a captive-born killer whale. International Zoo Yearbook, 27, 295-304. doi:10.1111/j.1748-1090.1988.tb03227.x

Barlowe, K., Deangelo, C., \& Reiss, D. (2001). Preliminary observations on maternal instruction in nursing behavior in bottlenose dolphins (Tursiops truncatus): Do mothers teach their female offspring how to nurse? In Anonymous (Ed.), Abstracts, 14th Biennial Conference on the Biology of Marine Mammals, Vancouver, British Columbia (p. 17). Lawrence, KS: Society for Marine Mammalogy.

Bauer, G. B. (1986). The behavior of humpback whales in Hawaii and modifications of behavior induced by human interventions (Unpublished doctoral dissertation). University of Hawaii, Honolulu, HI.

Béland, P., Faucher, A., \& Corbeil, P. (1990). Observations on the birth of a beluga whale (Delphinapterus leucas) in the St. Lawrence Estuary, Quebec, Canada. Canadian Journal of Zoology, 68, 1327-1329. doi:10.1139/z90-198

Bennett, F. D. (1840). Narrative of a whaling voyage round the globe, from the year 1833 to 1836. Comprising sketches of Polynesia, California, the Indian Archipelago, etc. with an account of southern whales, the sperm whale fishery, and the natural history of the climates visited. London: Richard Bentley.

Berzin, A. A. (1972). The sperm whale (kashalot). (Israel Program for Scientific Translations, Trans.). Izdatel'stvo Pishchevaya Promyshlennost, Moscow, Russia. (Original work published 1971)

Best, P. B., Canham, P. A. S., \& Macleod, N. (1984). Patterns of reproduction in sperm whales, Physeter macrocephalus. Reports of the International Whaling Commission, Special Issue 6, 51-79.

Best, P. B., Elwen, S. H., Palsbøll, P. J., Thornton, M., Austin, E., \& Vinding, K. (2015). Possible non-offspring nursing in the southern right whale, Eubalaena australis. Journal of Mammalogy, 96, 405-416. doi:10.1093/jmammal/gyv042

Boertmann, D., \& Nielsen, R. D. (2010). A bowhead whale calf observed in northeast Greenland waters. Polar Record, 46, 373-375. doi: 10.1017/S0032247410000070

Bullen, F. T. (1889). The cruise of the "Cachalot" round the world after sperm whales. London: Smith, Elder \& Co.

Busch, R. (1998). Gray whales: Wandering giants. Victoria, BC: Orca Book Publishers.

Caldwell, D. K., \& Caldwell, M. C. (1972). The world of the bottlenosed dolphin. St. Augustine, FL: Biological Systems.

Campbell, C. A. (2011). Comprehensive video ethogram on beluga (Delphinapterus leucas) behavior. (Unpublished master's thesis), Texas A\&M University, College Station, TX.

Camphuysen, C. J., \& Krop, A. (2011). Maternal care, calf-training and site fidelity in a wild harbour porpoise in the North Sea. Lutra, 54,123-126.

Caron, L. M. J. (1987). Status, site-fidelity, and behavior of a hunted herd of white whales (Delphinapterus leucas) in the Nastapoka Estuary, eastern Hudson Bay. (Unpublished master's thesis), McGill University, Montreal, Quebec.

Carroll, G. M., \& Smithhisler, J. R. (1980). Observations of bowhead whales during spring migration. Marine Fisheries Review, 42, 80-85.

Cartwright, R. (2005). A comparative study of the behaviour and dynamics of humpback whale (Megaptera novaeangliae) mother and calf pairs during their residence in nursery waters. (Unpublished doctoral dissertation), Manchester Metropolitan University, Manchester, UK.

Cartwright, R., \& Sullivan, M. (2009). Associations with multiple male groups increase the energy expenditure of humpback whale (Megaptera novaeangliae) female and calf pairs on the breeding grounds. Behaviour, 146, 1573-1600. doi:10.1163/156853909x458377

Chen, P., Liu, P., Liu, R., Lin, K., \& Pilleri, G. (1979). Distribution, ecology, behaviour and conservation of the dolphins of the middle reaches of Changjiang (Yangtze) River (Wuhan-Yueyang). Investigations on Cetacea, 10, 87-103.

Chirighin, L. (1987). Mother-calf spatial relationships and calf development in the captive bottlenose dolphin Tursiops truncatus. Aquatic Mammals, 13, 5-15.

Clapham, P. J., \& Mayo, C. A. (1987). Reproduction and recruitment of individually identified humpback whales, 
Megaptera novaeangliae, observed in Massachusetts Bay, 1979-1985. Canadian Journal of Zoology, 65, 2853-2863. doi:10.1139/z87-434

Clark, S. T., \& Odell, D. K. (1999a). Nursing parameters in captive killer whales (Orcinus orca). Zoo Biology, 18, 373-384. doi:10.1002/(sici)1098-2361(1999)18:5<373: aid-zoo2>3.0.co;2-d

Clark, S. T., \& Odell, D. K. (1999b). Nursing behavior in captive false killer whales (Pseudorca crassidens). Aquatic Mammals, 25, 183-191.

Clugston, D. A. (1974). The ontogeny of mother-infant behavior in the bottlenosed dolphin (Tursiops truncatus): Nursing and stimulation games. Unpublished study of mother and infant at Mystic Marinelife Aquarium, Mystic, CT.

Cockcroft, V. G., \& Ross, G. J. B. (1990). Observations on the early development of a captive bottlenose dolphin calf. In S. Leatherwood \& R. R. Reeves (Eds.), The bottlenose dolphin (pp. 461-478). San Diego, CA: Academic Press.

Condy, P. R., Van Aarde, R. J., \& Bester, M. N. (1978). The seasonal occurrence and behaviour of killer whales Orcinus orca, at Marion Island. Journal of Zoology, London, 184, 449-464. doi: 10.1111/j.14697998.1978.tb03301.x

Dana Point Whalewatching. (2016, October 9). Blue whale nursing mother and calf [Video File]. Retrieved from https://www.youtube.com/watch?v=oTIDLcKpApQ

Deakos, M. H., Branstetter, B. K., Mazzuca, L., Fertl, D., \& Mobley Jr., J. R. (2010). Two unusual interactions between a bottlenose dolphin (Tursiops truncatus) and a humpback whale (Megaptera novaeangliae) in Hawaiian waters. Aquatic Mammals, 36, 121-128. doi:10.1578/AM.36.2.2010.121

Deutsch, S. M. (2008). Behavioral development of dusky dolphins. (Unpublished master's thesis), Texas A\&M University, College Station, TX.

Dohl, T. P., Norris, K. S., \& Kang, I. (1974). A porpoise hybrid: Tursiops x Steno. Journal of Mammalogy, 55, $217-$ 221. doi: $10.2307 / 1379276$

Drinnan, R. L., \& Sadleir, R. M. F. S. (1981). The suckling behavior of a captive beluga (Delphinapterus leucas) calf. Applied Animal Ethology, 7, 179-185. doi:10.1016/0304-3762(81)90097-3

Dudley, P. (1725). An essay upon the natural history of whales, with a particular account of the ambergris found in the Sperma Ceti whale. Philosophical Transactions of the Royal Society of London, 33, 256-269. doi:10.1098/rstl.1724.0053

Dudok van Heel, W. H., \& Meyer, M. M. (1974). Birth in dolphins (Tursiops truncatus, Mont.) in the Dolphinarium, Harderwijk, Netherlands. Aquatic Mammals, 2, 11-23.

Dudzinski, K. M. (1996). Communication and behavior in the Atlantic spotted dolphins (Stenella frontalis): Relationships between vocal and behavioral activities. (Unpublished doctoral dissertation). Texas A\&M University, College Station, TX.

Dykstra, P. (2013, June 17). Blue whale exploration - Sri Lanka [Video File]. Retrieved from https://www.youtube.com/watch?v=KuXCTIdlXOk

Eastcott, A., \& Dickinson, T. (1987). Underwater observations of the suckling and social behaviour of a new-born bottlenosed dolphin (Tursiops truncatus). Aquatic Mammals, 13, 51-56.

Edds, P. L., \& Macfarlane, J. A. F. (1987). Occurrence and general behavior of balaenopterid cetaceans summering in the St. Lawrence Estuary, Canada. Canadian Journal of Zoology, 65, 1363-1376. doi:10.1139/z87-216

Edel, R. K., \& Winn, H. E. (1978). Observations on underwater locomotion and flipper movement of the humpback whale Megaptera novaeangliae. Marine Biology, 48, 279-287. doi:10.1007/BF00397155

Essapian, F. S. (1953). The birth and growth of a porpoise. Natural History, 62, 392-399.

Fellner, W. (2000). Synchrony between a mother-calf pair of bottlenose dolphins (Tursiops truncatus). (Unpublished master's thesis). New College of the University of South Florida, Sarasota, FL.

Ferreira, M. E. C., Maia-Nogueira, R., \& Hubner de Jesus, A. (2014). Surface observation of a birth of a humpback whale (Megaptera novaeangliae) on the northeast coast of Brazil. Latin American Journal of Aquatic Mammals, 9, 160-163. doi:10.5597/lajam00182

Foley, H. J., Holt, R. C., Hardee, R. E., Nilsson, P. B., Jackson, K. A., Read, A. J., ...McLellan, W. A. (2011). Observations of a western North Atlantic right whale (Eubalaena glacialis) birth offshore of the protected southeast U.S. critical habitat. Marine Mammal Science, 27, E234-E240. doi:10.1111/j.17487692.2010.00452.x

Gero, S., \& Whitehead, H. (2007). Suckling behavior in sperm whale calves: Observations and hypotheses. Marine Mammal Science, 23, 398-413. doi:10.1111/j.1748-7692.2007.00113.x

Giradeau, M. G. [Mark G Media] (2015, July 12). First known aerial of nursing blue whales [Video File]. Retrieved from https://www.youtube.com/watch?v=9-_EJVI7Mns 
Glockner-Ferrari, D. A., \& Ferrari, M. J. (1984). Reproduction in humpback whales, Megaptera novaeangliae, in Hawaiian waters. Reports of the International Whaling Commission, Special Issue 6, 237-242.

Glockner-Ferrari, D. A., \& Ferrari, M. J. (1985). Individual identification, behavior, reproduction and distribution of humpback whales, Megaptera novaeangliae, in Hawaii. Washington, DC: Marine Mammal Commission. (NTIS PB85-200772).

Glockner, D. A., \& Venus, S. C. (1983). Individual identification, growth rate, and behavior of humpback whale, Megaptera novaeangliae, cows and calves in the waters off Maui, Hawaii, 1977-1979. In R. Payne (Ed.), Communication and behavior of whales (pp. 223-258). Boulder, CO: Westview Press.

Gordon, J. C. D. (1987). The behaviour and ecology of sperm whales off Sri Lanka. (Unpublished doctoral dissertation). University of Cambridge, Cambridge, UK.

Gordon, J. C. D. (1991). The World Wildlife Fund's Indian Ocean Sperm Whale Project: An example of cetacean research within the Indian Ocean Sanctuary. In S. Leatherwood, \& G. P. Donovan (Ed.), Cetaceans and cetacean research in the Indian Ocean Sanctuary (pp. 219-239). Nairobi, Kenya: United Nations Environment Programme.

Gubbins, C., McCowan, B., Lynn, S. K., Hooper, S., \& Reiss, D. (1999). Mother-infant spatial relations in captive bottlenose dolphins. Marine Mammal Science, 15, 751-765. doi: 10.1111/j.1748-7692.1999.tb00841.x

Gurevich, V. S. (1977). Post-natal behavior of an Atlantic bottlenosed dolphin calf (Tursiops truncatus, Montagu) born at Sea World. In S. H. Ridgway \& K. Benirschke (Eds.), Breeding dolphins; present status, suggestions for the future (pp. 168-184). Washington, DC: Marine Mammal Commission. (NTIS PB273673).

Haenel, N. J. (1986). General notes on the behavioral ontogeny of Puget Sound killer whales and the occurrence of allomaternal behavior. In B. C. Kirkevold \& J. S. Lockard (Eds.), Behavioral biology of killer whales (pp. 285-300). New York, NY: Alan R. Liss, Inc.

Hain, J. H. W., Hampp, J. D., McKenney, S. A., Albert, J. A., \& Kenney, R. D. (2013). Swim speed, behavior, and movement of North Atlantic right whales (Eubalaena glacialis) in coastal waters of northeastern Florida, USA. PLoS ONE, 8, e54340. doi:10.1371/journal.pone.0054340

Hamilton, P. K., \& Cooper, L. A. (2010). Changes in North Atlantic right whale (Eubalaena glacialis) cow-calf association times and use of the calving ground: 1993-2005. Marine Mammal Science, 26, 896-916. doi:10.1111/j.1748-7692.2010.00378.

Hewlett, S. R. (1978). It's a boy, at the Vancouver Aquarium. Animal Kingdom, 81, 15-27.

Hofmann, B., Scheer, M., \& Behr, I. P. (2004). Underwater behaviors of short-finned pilot whales (Globicephala macrorhynchus) off Tenerife. Mammalia, 68, 221-224. doi:10.1515/mamm.2004.020

Jacobsen, J. K. (1986). The behavior of Orcinus orca in the Johnstone Strait, British Columbia. In B. C. Kirkevold \& J. S. Lockard (Eds.), Behavioral biology of killer whales (pp. 135-185). New York, NY: Alan R. Liss, Inc.

Jacobsen, T. B., Mayntz, M., \& Amundin, M. (2003). Splitting suckling data of bottlenose dolphin (Tursiops truncatus) neonates in human care into suckling bouts. Zoo Biology, 22, 477-488. doi:10.1002/zoo.10094

Johnson, C. M., \& Norris, K. S. (1994). Social behavior. In K. S. Norris, B. Würsig, R. S. Wells, \& M. Würsig (Eds.), The Hawaiian spinner dolphin (pp. 243-286). Berkeley, CA: University of California Press.

Johnson, G., Frantzis, A., Johnson, C., Alexiadou, V., Ridgway, S., \& Madsen, P. T. (2010). Evidence that sperm whale (Physeter macrocephalus) calves suckle through their mouth. Marine Mammal Science, 26, 990996. doi:10.1111/j.1748-7692.2010.00385.x

Joseph, B. E., Antrim, J. E., \& Cornell, L. H. (1987). Commerson's dolphin (Cephalorhynchus commersoni): A discussion of the first live birth within a marine zoological park. Zoo Biology, 6, 69-77. doi:10.1002/zoo.1430060108

Kastelein, R. A., Dokter, T., \& Zwart, P. (1990). The suckling of a Bottlenose dolphin calf (Tursiops truncatus) by a foster mother, and information on transverse birth bands. Aquatic Mammals, 16, 134-138.

Kastelein, R. A., McBain, J., \& Neurohr, B. (1993). Information on the biology of Commerson's dolphins (Cephalorhynchus commersonii). Aquatic Mammals, 19, 13-19.

Kasuya, T. (1999). Finless porpoise Neophocaena phocaenoides (G. Cuvier, 1829). In S. H. Ridgway \& R. Harrison (Eds.), Handbook of marine mammals, Vol 6: The second book of dolphins and the porpoises (pp. 411442). San Diego, CA: Academic Press.

Krasnova, V. V., Bel'kovich, V. M., \& Chernetsky, A. D. (2006). Mother-infant spatial relationships in wild beluga (Delphinapterus leucas) during postnatal development under natural conditions. Biological Bulletin, 33, 53-58. doi:10.1134/S1062359006010079

Kuczaj II, S. A., \& Yeater, D. B. (2007). Observations of rough-toothed dolphins (Steno bredanensis) off the coast 
of Utila, Honduras. Journal of the Marine Biological Association of the United Kingdom, 87, 141-148. doi:10.1017/S0025315407054999

Lefèvre, Y., Leborgne, E., \& Gannier, A. (1999). An abnormal calf of humpback whale observed off Rurutu Island (French Polynesia). European Research on Cetaceans, 13, 367-368.

Leung, E. S., Vergara, V., \& Barrett-Lennard, L. G. (2010). Allonursing in captive belugas (Delphinapterus leucas). Zoo Biology, 29, 633-637. doi:10.1002/zoo.20295.

Liu, R., Klinowska, M., \& Harrison, R. J. (1986). The behaviour of Lipotes vexillifer and Neophocaena phocaenoides in the Changjiang River and in captivity in China. In M. M. Bryden \& R. Harrison (Eds.), Research on dolphins (pp. 433-439). Oxford, UK: University Press.

Mann, J., \& Smuts, B. (1999). Behavioral development in wild bottlenose dolphin newborns (Tursiops sp.). Behaviour, 136, 529-566.

Mann, J., Connor, R. C., Barre, L. M., \& Heithaus, M. R. (2000). Female reproductive success in bottlenose dolphins (Tursiops sp.): Life history, habitat, provisioning, and group-size effects. Behavioral Ecology, 11, 210-219. doi:10.1093/beheco/11.2.210

Markowitz, W. J. (2012). Comparative socioecology of the dusky dolphin (Lagenorynchus obscurus) in New Zealand. (Unpublished doctoral dissertation). Massey University, Manawatu, New Zealand.

McBride, A. F., \& Kritzler, H. (1951). Observations on pregnancy, parturition, and post-natal behavior in the bottlenose dolphin. Journal of Mammalogy, 32, 251-266. doi:10.2307/1375657

Mello, I., Nordensten, L., \& Amundin, M. (2005). Reactions of three bottlenose dolphin dams with calves to other members of the group in connection with nursing. Zoo Biology, 24, 543-555. doi:10.1002/zoo.20071

Miles, J. A., \& Herzing, D. L. (2003). Underwater analysis of the behavioural development of free-ranging Atlantic spotted dolphin (Stenella frontalis) calves (birth to 4 years of age). Aquatic Mammals, 29, 363-377.

Morete, M. E., Freitas, A., Engel, M. H., Pace, R. M., \& Clapham, P. J. (2003). A novel behavior observed in humpback whales on wintering grounds at Abrolhos Bank (Brazil). Marine Mammal Science, 19, 694-707. doi:10.1111/j.1748-7692.2003.tb01125.x

Morisaka, T., Kohshima. S., Yoshioka, M., Suzuki, M., \& Nakahara, F. (2010). Recent studies on captive cetaceans in Japan: Working in tandem with studies on cetaceans in the wild. International Journal of Comparative Psychology, 23, 644-663.

Morisaka, T., Shinohara, M., \& Taki, M. (2005). Underwater sounds produced by neonatal bottlenose dolphins (Tursiops truncatus): II. Potential function. Aquatic Mammals, 31, 258-265. doi:10.1578/AM.31.2.2005.258

National Geographic. (2016, March 6). Exclusive video may show blue whale calf nursing. Retrieved from http://news.nationalgeographic.com/2016/03/160302-blue-whale-mother-calf-nursing-video-pygmy-newzealand/

Norris, K. S., \& Dohl, T. P. (1980). Behavior of the Hawaiian spinner dolphin, Stenella longirostris. Fishery Bulletin, 77, 821-849.

Notarbartolo di Sciara, G. (1983). Bryde's whales (Balaenoptera edeni Anderson, 1878) off eastern Venezuela (Cetacea, Balaenopteridae). (HSWRI Tech. Rep. 83-153). San Diego, CA: Hubbs-Sea World Research Institute.

Patenaude, N. J. (2000). Southern right whales wintering in the Auckland Islands. (Conservation Advisory Science Notes No. 321). Wellington, New Zealand: Department of Conservation.

Peddemors, V. M., Fothergill, M., \& Cockcroft, V. G. (1992). Feeding and growth in a captive-born bottlenose dolphin Tursiops truncatus. South African Journal of Zoology, 27, 74-80.

Pilleri, G., \& Chen, P. (1979). How the finless porpoise (Neophocaena asiaeorientalis) carries its calves on its back, and the function of the denticulated area of skin, as observed in the Changjiang River, China. Investigations on Cetacea, 10, 105-108.

Press, R. (2015, October 21). UAV reveals killer whales in striking detail. Retrieved from http://www.fisheries.noaa.gov/podcasts/2015/10/uav_killer_whale.html

Rakhmawati, H. (2013). Tingkah laku menyusu dan makan anak lumba-lumba hidung boto (Tursiops aduncus) dalam captivity ex situ (Nursing and feeding behaviors of calf bottlenose dolphin (Tursiops aduncus) in captivity ex situ) Yogyakarta, Indonesia: Universitas Gadjah Mada Yogyakarta.

Reeves, R. R., Smith, T. D., Lund, J. N., Lebo, S. A., \& Josephson, E. A. (2010). Nineteenth-century ship-based catches of gray whales, Eschrichtius robustus, in the eastern North Pacific. Marine Fisheries Review, 72, $26-65$.

Reid, K., Mann, J., Weiner, J. R., \& Hecker, N. (1995). Infant development in two aquarium bottlenose dolphins. Zoo Biology, 14, 135-147. doi:10.1002/zoo.1430140207 
Richardson, W. J., Greene Jr., C. R., Koski, W. R., Malme, C. L., Miller, G. W., Smultea, M. A., \& Würsig, B. (1990). Acoustic effects of oil production activities on bowhead and white whales visible during spring migration near Pt. Barrow, Alaska - 1989 phase: Sound propagation and whale responses to playbacks of continuous drilling noise from an ice platform, as studied in pack ice conditions. (OCS Study MMS 900017). Herndon, VA: Minerals Management Service.

Ridgway, S., Kamolnick, T., Reddy, M., Curry, C., \& Tarpley, R. J. (1995). Orphan-induced lactation in Tursiops and analysis of collected milk. Marine Mammal Science, 11, 172-182. doi:10.1111/j.17487692.1995.tb00516.x

Russell, J. M., Simonoff, J. S., \& Nightingale, J. (1997). Nursing behaviors of beluga calves (Delphinapterus leucas) born in captivity. Zoo Biology, 16, 247-262. doi:10.1002/(SICI)1098-2361(1997)16:3<247:AID$\mathrm{ZOO5}>3.0 . \mathrm{CO} ; 2-\mathrm{A}$

Saayman, G. S., \& Tayler, C. K. (1979). The socioecology of humpback dolphins (Sousa sp.). In H. E. Winn \& B. L. Olla (Eds.), Behavior of marine animals, Vol. 3: Cetaceans (pp. 165-226). New York, NY: Plenum Press.

Sakai, M., Kita, Y. F., Kogi, K., Shinohara, M., Morisaka, T., Shiina, T., \& Inoue-Murayama, M. (2016). A wild Indo-Pacific bottlenose dolphin adopts a socially and genetically distant neonate. Scientific Reports, 6 , 23902. doi: 23910.21038/srep23902

Sakai, M., Morisaka, T., Iwasaki, M., Yoshida, Y., Wakabayashi, I., Seko, A., Kasamatsu, M., ...Kohshima, S. (2013). Mother-calf interactions and social behavior development in Commerson's dolphins (Cephalorhynchus commersonii). Journal of Ethology, 31, 305-313. doi:10.1007/s10164-013-0380-2

Santillán, L., Roca, M., Apaza, M., Oliviera, L. R., \& Ontón, K. (2004). New record of mother-calf pair of southern right whale, Eubalaena australis, off the Peruvian coast. Latin American Journal of Aquatic Mammals, 3, 83-84. doi:10.5597/lajam00053

Scammon, C. M. (1874). The marine mammals of the north-western coast of North America, described and illustrated; together with an account of the American whale-fishery. San Francisco, CA: John H. Carmany and Company.

Schaffar-Delaney, A. (2004). Female reproductive strategies and mother-calf relationships of common dolphins (Delphinus delphis) in the Hauraki Gulf, New Zealand. (Unpublished master's thesis). Massey University, Albany, New Zealand.

Schroeder, J. P. (1990). Breeding bottlenose dolphins in captivity. In S. Leatherwood \& R. R. Reeves (Eds.), The bottlenose dolphin (pp. 435-446). San Diego, CA: Academic Press.

Sergeant, D. E., \& Brodie, P. F. (1975). Identity, abundance, and present status of populations of white whales, Delphinapterus leucas, in North America. Journal of the Fisheries Research Board of Canada, 32, 10471054. doi:10.1139/f75-123

Silva Jr., J. M., Silva, F. J. L., \& Sazima, I. (2005). Rest, nurture, sex, release, and play: Diurnal underwater behaviour of the spinner dolphin at Fernando de Noronha Archipelago, SW Atlantic. Journal of Ichthyology and Aquatic Biology, 9, 161-176.

Starrett, A., \& Starrett, P. (1955). Observations on young blackfish, Globicephala. Journal of Mammalogy, 36, 424-429. doi:10.2307/1375685

Steiner, L., Silva, M. A., Zereba, J., \& Leal, M. J. (2007). Bryde's whales, Balaenoptera edeni, observed in the Azores: A new species record for the region. JMBA2-Biodiversity Records, 1, doi:10.1017/S1755267207007282

Stensland, E., \& Berggren, P. (2007). Behavioural changes in female Indo-Pacific bottlenose dolphins in response to boat-based tourism. Marine Ecology Progress Series, 332, 225-234. doi:10.3354/meps332225

Swartz, S. L. (1986). Gray whale migratory, social and breeding behavior. Reports of the International Whaling Commission, Special Issue 8, 207-229.

Sychenko, O. A. (2011). Western gray whale (Eschrichtius robustus) mother and calf ecology off Sakhalin Island. (Unpublished master's thesis). Texas A\&M University, College Station, TX.

Tavolga, M. C., \& Essapian, F. S. (1957). The behavior of the Bottle-nosed Dolphin (Tursiops truncatus): Mating, pregnancy, parturition and mother-infant behavior. Zoologica, 42, 11-31.

Thomas, P. O., \& Taber, S. M. (1984). Mother-infant interaction and behavioral development in southern right whales, Eubalena australis. Behaviour, 88, 42-60. doi:10.1163/156853984X00470

Tomilin, A. G. (1967). Mammals of the U.S.S.R. and adjacent countries. Vol. IX: Cetacea. (Israel Program for Scientific Translations, Trans.). Academy of Science, Moscow, Russia: Academy of Science. (Original work published 1957).

Torres, L., \& Klinck, H. (2016). Blue whale ecology in the South Taranaki Bight region of New Zealand. JanuaryFebruary 2016 Field Report. Newport, OR: Oregon State University. 
Triossi, F., Pace, D. S., Terranova, M. L., \& Renzi, P. (1998). The development of suckling behavior in two captiveborn calves of bottlenose dolphin (Tursiops truncatus). Aquatic Mammals, 24, 75-83.

Uwagbae, M., \& Van Waerebeek, K. (2010, June). Initial evidence of dolphin takes in the Niger Delta region and a review of Nigerian cetaceans. Working paper SC/62/SM1 presented to the Scientific Committee of the International Whaling Commission, Agadir, Morocco. Retrieved from https://iwc.int/document_1454

Van Waerebeek, K., Reyes, J. C., \& Van Bressam, M. F. (1998). Sighting of a mother-calf pair of Southern Right whale Eubalaena australis in Peruvian waters. Estudios Oceanologicos, 17, 105-107.

Van Waerebeek, K., Tchibozo, S., Montcho, J., Nobime, G., Sohou, Z., Sohouhoue, P., \& Dossou, C. (2001, July). The Bight of Benin, a North Atlantic breeding ground of a Southern Hemisphere humpback whale population, likely related to Gabon and Angola substocks. Working paper SC/53/IA21 presented to the Scientific Committee of the International Whaling Commission, London, England. Retrieved from www.vliz.be/imisdocs/publications/243239.pdf

Visser, I. (2000). Killer whale (Orcinus orca) interactions with longline fisheries in New Zealand waters. Aquatic Mammals, 26, 241-252.

von Streit, C., Ganslosser, U., \& von Fersen, L. (2011). Ethogram of two captive mother-calf dyads of bottlenose dolphins (Tursiops truncatus): Comparison with field ethograms. Aquatic Mammals, 37, 193-197. doi:10.1578/AM.37.2.2011.193

von Streit, C., Ganslosser, U., \& von Fersen, L. (2013). Behavioral development of two captive mother-calf dyads of bottlenose dolphins (Tursiops truncatus) in the calves' first year. International Journal of Comparative Psychology, 26, 176-196. doi:10.1578/AM.37.2.2011.193

Wei, Z., Wang, D., Kuang, X., Wang, K., Wang, X., Xiao, J., ... Zhang, X. (2002). Observations on behavior and ecology of the Yangtze finless porpoise (Neophocaena phocaenoides asiaeorientalis) group at Tian-e-Zhou Oxbow of the Yangtze River. Raffles Bulletin of Zoology, Supplement 10, 97-103.

Wells, R. S. (1991). Bringing up baby. Natural History, 100, 56-62.

Whitehead, H. (2003). Sperm whales: Social evolution in the ocean. Chicago, IL: University of Chicago Press.

Williamson, G. R. (1961). Winter sightings of a humpback suckling its calf on the Grand Bank of Newfoundland. Norsk Hvalfangst-Tidende, 50, 1-5.

Würsig, B., \& Clark, C. (1993). Behavior. In J. J. Burns, J. J. Montague, \& C. J. Cowles (Eds.), The bowhead whale (pp. 157-199). Lawrence, KS: Society for Marine Mammalogy.

Würsig, B., Clark, C. W., Dorsey, E. M., Richardson, W. J., \& Wells, R. S. (1983). Normal behavior of bowheads, 1982. In W. J. Richardson (Ed.), Behavior, disturbance responses and distribution of bowhead whales Balaena mysticetus in the eastern Beaufort Sea, 1982 (pp. 25-115). Bryan, TX: LGL Ecological Research Associates Inc. Retrieved from https://www.boem.gov/BOEMNewsroom/Library/Publications/1983/1983_behavior_bowheads.aspx

Würsig, B., Dorsey, E. M., Fraker, M. A., Payne, R. S., Richardson W. J., \& Wells, R. S. (1984). Behavior of bowhead whales, Balaena mysticetus, summering in the Beaufort Sea: Surfacing, respiration, and dive characteristics. Canadian Journal of Zoology, 62, 1910-1921. doi:10.1139/z84-281

Würsig, B., Dorsey, E. M., Fraker, M. A., Payne, R. S., \& Richardson, W. J. (1985). Behavior of bowhead whales, Balaena mysticetus, summering in the Beaufort Sea: A description. Fishery Bulletin, 83, 357-377.

Würsig, B., Dorsey, E. M., Fraker, M. A., Payne, R. S., \& Richardson, W. J. (1986). Behavior of bowhead whales, Balaena mysticetus, summering in the Beaufort Sea: A summary. Reports of the International Whaling Commission, Special Issue 8, 167-175.

Würsig, B., Koski, W. R., \& Richardson, W. J. (1999). Whale riding behavior: Assisted transport for bowhead whale calves during spring migration in the Alaskan Beaufort Sea. Marine Mammal Science, 15, 204-210. doi:10.1111/j.1748-76921999.tb00791.x

Xian, Y., Wang, K., Jiang, W., Zheng, B., \& Wang, D. (2010). Ethogram of Yangtze finless porpoise calves (Neophocaena phocaenoides asiaeorientalis). Zoological Research, 31, 523-530. doi:10.3724/SP.J.1141.2010.05523

Xian, Y., Wang, K., Xiao, J., \& Wang, D. (2012). Suckling behavior and its development in two Yangtze finless porpoise calves in captivity. Zoo Biology, 31, 229-234. doi:10.1002/zoo.20391

ZooBorns. (2012, June 11). Update! Shedd Aquarium's baby dolphin nurses. Retrieved from http://www.zooborns.com/zooborns/2012/06/shedd-dolphin-calf-nurses.html 